\title{
Translation and Linguistic Validation of the Korean Version of the Wisconsin Stone Quality of Life Questionnaire
}

\author{
Young Eun Yoon ${ }^{1}$, Sung Yong $\mathrm{Cho}^{2,3}$ \\ ${ }^{1}$ Department of Urology, Hanyang University College of Medicine, Seoul, Korea \\ ${ }^{2}$ Department of Urology, Seoul National University Hospital, Seoul, Korea \\ ${ }^{3}$ Department of Urology, Seoul Metropolitan Government - Seoul National University Boramae Medical Center, Seoul, Korea
}

Purpose: Although cure rate and efficacy of treatment for urinary stone disease have been improved, clinicians have been indifferent to the quality of life (QoL) of stone patients in Korea. The objective of this study was to develop a Korean version of Wisconsin questionnaire about quality of life questionnaire (K-WISQOL) of stone patients for use in Korea.

Methods: Linguistic validation was permitted for translation by its developers. Three bilingual nonspecialists and 11 panels who were actively involved in treating urinary stone patients performed the translation and linguistic validations. A trained interviewer and 5 Korean patients carried out cognitive debriefing.

Results: Noun words such as "energy" and "responsibilities" were very difficult to translate to Korean. They were substituted by more comprehensive words. After backward translation, translated sentences showed a good agreement with the original WISQOL. During backward translation and the second reconciliation, previously translated Korean version was revised in 5 sentences. In the cognitive debriefing process, all 5 patients thought that these questions explained the patient's situation well. Most of these respondents answered that explanatory notes of questionnaire were well written and the format of the questionnaire was easy to follow.

Conclusions: The present study demonstrated that, despite language differences, translation and linguistic validation of the KWISQOL were successfully performed. This K-WISQOL could be useful tools for treatment plan and patient care.

Keywords: Urolithiasis; Quality of life; Urination; Validation study

- Fund/Grant Support: The study protocol was supported by the Investigational Research Committee of the Korean Continence Society and the Young Endourological Study (YES) group.

- Research Ethics: The Institutional Review Board of Seoul Metropolitan Government - Seoul National University Boramae Medical Center approved the linguistic validation of the Wisconsin Stone Quality of Life Questionnaire (approval number: 26-2016-60).

- Conflict of Interest: SYC is one of the members of the Editorial Board of International Neurourolgy Journal. However, he played no role whatsoever in the editorial evaluation of this article or the decision the publish it. Except for that, no potential conflict of interest relevant to this article was reported.

\section{INTRODUCTION}

Renal stone disease is a common urological condition. The prevalence of urinary calculi has been increasing, despite the generalization of supplying clean water and the development of treatment skills for increasing stone-free rates [1-4]. Although the development of extracorporeal shock wave lithotripsy and endoscopic surgery such as ureteroscopic removal of stone and percutaneous nephrolithotomy (PCNL) have made urinary calculi relatively easy to treat, recurrence rate remains high. There-

Corresponding author: Sung Yong Cho (iD https://orcid.org/0000-0001-9271-6951 Department of Urology, Seoul National University Hospital, 101 Daehak-ro, Jongno-gu, Seoul 03080, Korea

E-mail: kmoretry@daum.net

Submitted: November 11, 2018 / Accepted after revision: August 28, 2019 
fore, many stone formers suffer from repetitive flank pain and anxiety about going to the emergency room because of stonerelated symptoms and health problems. Additionally, deterioration of renal function is induced by long-term ureter obstruction, stone-related pain, urinary tract infection, or reintervention which may adversely affect the quality of life (QoL) of patients. This emphasizes the importance of evaluating QoL of patients' daily lives. The QoL of patients with stones would be inevitably lower than that of those without history of stones. However, studies on the QoL of patients with urinary stone are rarely conducted. Although many studies have been published about the development of new treatment methods or the efficiency of treatment, few studies have focused on QoL of patients with urinary stone. The importance of QoL for patients with urinary stone has recently begun to be acknowledged and several studies have been published up to date [5-17]. With increasing interest in QoL of patients with urinary stone, research has also focused on how to evaluate QoL more accurately. Consequently, several questionnaires have been suggested for patients with urinary stone $[7,16]$.

Wisconsin Stone Quality of Life Questionnaire (WISQOL) developed by Penniston et al. [6] has been relatively widely used and cited. It not only evaluates QoL of stone formers, but also evaluates QoL of patients who have undergone surgery due to urinary stones $[12,13]$. The questionnaire consisted of 28 questions to evaluate QoL of stone formers with help from 34 stone patients. They initially generated 65 items and reduced them depending on the frequency and importance of symptoms. These 28 questions were grouped intuitively into the following 7 domains: (1) energy and fatigue, (2) sleep, (3) work and family, (4) nutrition and pharmacological therapies, (5) physical symptoms, (6) concerns related to intimacy and travel, and (7) general emotional well-being [7].

However, a qualified assessment tool for patients with urinary stone in Korea is lacking. Therefore, the objective of this study was to make a Korean version of WISQOL. The present study describes the development of Korean version of WISQOL based on the original English version with subsequent linguistic validation by a panel of Korean specialists and patients with history of urinary stone.

\section{MATERIALS AND METHODS}

\section{Translation and Linguistic Validation}

This study was approved by the Institutional Review Board. The authors followed previously designated processes (Fig. 1) designed to obtain a well-translated Korean version of WISQOL so that it would be conceptually identical to the original version $[18,19]$. The original version was translated or paraphrased in accordance with Korean cultural and social differences. It was carried out by project leaders (YEY and SYC) of the panel. This panel called Young Endourological Study Group consisted of 13 Korean experts who performed a typical linguistic validation process. They were urologists who were actively treating patients with urolithiasis.

\section{Permission}

Before the present study began, the panel contacted the Wisconsin group to gain permission to translate and use WISQOL with language validation process.

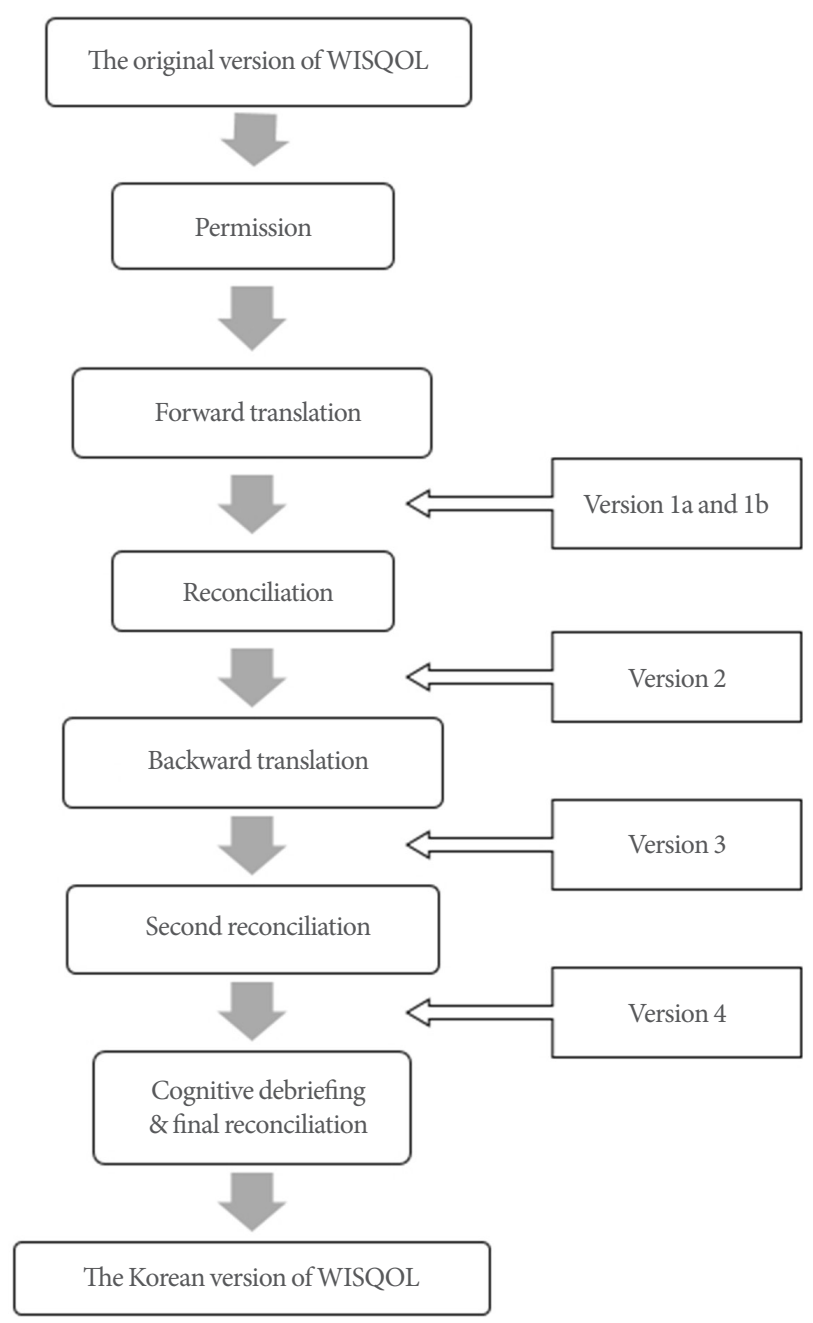

Fig. 1. The linguistic validation algorithm. WISQOL, Wisconsin Stone Quality of Life Questionnaire. 


\section{Forward Translation}

The original version of WISQOL was translated into Korean by 2 bilingual (Korean and English) translators who did not have a medical license (ver. 1a and 1b). One was an accountant working on international affairs. The other was a doctoral student majoring in natural science in a graduate school of the United States. Only one researcher (YEY) contacted 2 translators respectively. Contacts were made only through emails. The 2 translators were unaware of each other. Discussion between the 2 translators was not allowed during the translation process.

\section{Reconciliation by Panel}

Translated WISQOL by 2 translators were combined into 1 file and reconciliated into a single version through 2 panel meetings and several electronic conversations. There was difficulty because of the existence of some honorific expression only in Korean, not in English. Thus, a lot of discussion was necessary about expressions in English without such expression in Korea due to cultural differences. After many adjustments, panel was able to complete a reconciliated Korean version of WISQOL (ver. 2).

\section{Backward Translation}

Backward translation was performed by another bilingual translator who did not know the original version of WISQOL. This translator was a graduate student majoring in biology at a university in the United States and preparing a doctorate in Korea. As before, we only contacted the translator via email. The third translator was isolated from the previous 2 translators. This translator translated reconciliated Korean version (ver. 2) back into an English version (ver. 3).

\section{Second Reconciliation by Panel}

After the third translator completed the task, all panels assembled to make the final adjustment. Several differences were de- tected between the original version and ver. 3. All panels including 3 translators carried out reconciliation on this. After that, all sentences were made as one questionnaire in the same shape according to the original arrangement of WISQOL (ver. 4). As the questionnaire was completed, spellings and grammars were checked by careful proofreading.

\section{Cognitive Debriefing and Final Reconciliation}

WISQOL ver. 4 was given to 5 Korean recurrent stone formers at the center of the author (SYC). Patients gave information about whether they had difficulty in reading or understanding the questionnaire without any help or whether there was ambiguous expression. After they finished the questionnaire, a well-trained interviewer who was a nurse practitioner in the center of the author (SYC) interviewed these patients. The interviewer gathered and gave their opinions to the panel. The panel finally discussed whether further correction was needed.

\section{RESULTS}

\section{Forward Translation and Reconciliation}

As experienced in previous research, the choice of words (especially nouns) was very tricky. There were some expressions that we had difficulty in word selection despite many panel meetings and discussions (Table 1). Supplementary Table 1 shows all items of forward translation and reconciliation.

The first sentence (1-A) in the first question group "My energy level during the day is less than usual." is translated into "Nat donganui eneoji reberi pyeongsoboda natda." (Energy levels during the day are lower than usual.) and "Pyeongsoboda giryeogi eopda." (There is no energy than usual). However, the panel concluded that there was no Korean synonym for the English noun "energy." It is usually called "eneoji” in Korea. However, it is very different from the meaning of energy in this sentence

Table 1. Expressions that were difficult for forward translation

\begin{tabular}{|c|c|c|c|}
\hline Original English expressions & $\begin{array}{c}\text { Forward Korean translation by } \\
\text { translator } 1 \text { (ver. 1a) }\end{array}$ & $\begin{array}{c}\text { Forward Korean translation by } \\
\text { translator } 2 \text { (ver. } 1 \mathrm{~b})\end{array}$ & $\begin{array}{c}\text { Reconciled forward Korean } \\
\text { translation (ver. 2) }\end{array}$ \\
\hline Energy level & 에너지 레벨 & 기력 & 기력 수준 \\
\hline Attend or participate in social events & 사교적인 모임에 참석 & 사회생활 참여 & 사교 모임에 참석, 혹은 참여 \\
\hline To fulfill other responsibilities & 다른 맡은 일을 하기 위해 & 다른 일들을 하기 위해 & 다른 책임들을 수행 \\
\hline Other commitments & - & 다른 일들 & 약속된 일들 \\
\hline Stomach upset or cramps & 복통 혹은 위경련 & 소화 불량 또는 복통 & 배탈 혹은 위경련 \\
\hline Socializing/being around others & 사교 활동 혹은 남들과 어울리는 것 & 다른 사람들과 만나거나 함께 있는 것 & 사교/타인과 어울리는 것 \\
\hline
\end{tabular}


when Koreans use this expression. In addition, there is a high possibility that elderly patients would not understand "eneoji" because it is a loanword. Therefore, the panel reconciled that energy should be changed into "giryeok sujun" (power level).

The panel also had trouble for the second sentence (3-B) in the third question group "I force myself to go to work or school, to exercise, or to fulfill other responsibilities." Translators translated this into "Jikjangina hakgyoe gagi wihae, undonghareo gagi wihae, hogeun dareun mateun ireul hagi wihae eokjiro noryeokaeya handa." (I have to try hard to go to work or school, go to workout, or do other jobs.) or "Irina hakgyoe gageona, undong ttoneun dareun ildeureul hagi wihaeseoneun eokjiro haeyahanda." (Have to force myself to go to work or school, exercise or do other things.). The main reason why this sentence is difficult to translate is because there is no proper word to replace "fulfill other responsibilities" in Korean. The panel discussed about this and it was interpreted as "dareun chaegimdeureul suhaenghanda" (carry out other responsibilities) after discussion.

\section{Backward Translation and the Second Reconciliation}

Contents of Korean WISQOL version 2 were revised for a total of 5 sentences (Table 2). The reconciled version of the WISQOL (ver. 2.) was sent to a third translator by email and the third translator performed backward translation to version 3 which was compared with the original version of WISQOL. These translated sentences showed a good agreement with the original WISQOL (Supplementary Table 2).

In question 7-2, there was an expression "everyday issues or responsibilities." However, after backward translation, it was changed to "everyday tasks and responsibilities." In version 2, the word "issues" was translated into Korean "ildeul." In English, issues and tasks mean quite different meanings. However, panels concluded that there were no proper Korean words to represent "issues" through discussion. Therefore, the authors concluded that no modifications were needed in this sentence.

There were differences in backward translation due to different tense grammars of English and Korean for questions about the last 4 weeks of experience of the last session. These questions are based on past tense sentences while asking about past 4-week experiences. Backward translator translated these into sentences of present perfect tense. In panel reconciliation, panels concluded that this part was not considered to be a problem to understand and this issue was inevitable because of different tenses of English and Korean.

\section{Cognitive Debriefing and Final Reconciliation}

The translated WISQOL was given to 5 patients and tested to make sure that they understood these questions. All patients were regularly followed up in the urology outpatient clinic of the center of the author (SYC) due to urinary lithiasis. Their ages ranged from 20 s to 60 s. Patients were able to understand all sentences well. However, 2 of these patients aged over 60 years had to read these questions 2 or 3 times to understand these questions. Because all the questions are based on the last 4 weeks of experience, patients who underwent surgery recently wondered if they had to answer based on preoperative conditions or postoperative symptoms. All patients answered yes to the question whether these questions explained the patients' situation well. Most of these responders answered that explanatory notes of the questionnaire were well written and the format

Table 2. Modified Korean expressions from version 2 after backward translation

\begin{tabular}{|c|c|c|c|}
\hline Original English item & $\begin{array}{l}\text { Reconciled forward Korean } \\
\text { translation (ver. 2) }\end{array}$ & $\begin{array}{l}\text { Backward English translation by } \\
\text { translator } 3 \text { (ver. 3) }\end{array}$ & $\begin{array}{l}\text { Finally reconciled Korean } \\
\text { translation (ver. } 4 \text { ) }\end{array}$ \\
\hline Mostly true & 대체로 해당됨 & Generally applicable & 거의 해당됨 \\
\hline $\begin{array}{l}\text { Needing to get up frequently } \\
\text { while sleeping to urinate }\end{array}$ & $\begin{array}{l}\text { 소변을 보기 위해 잠자는 도중에 } \\
\text { 자주 깨야 한다. }\end{array}$ & $\begin{array}{l}\text { Have to wake up often from sleep } \\
\text { to urinate }\end{array}$ & $\begin{array}{l}\text { 소변을 보기 위해 잠자는 도중에 } \\
\text { 자주 깨야 할 필요가 있다. }\end{array}$ \\
\hline $\begin{array}{l}\text { I don't feel the usual freedom } \\
\text { to travel or to attend or } \\
\text { participate in social events }\end{array}$ & $\begin{array}{l}\text { 나는 여행을 하거나 사교 모임에 참석, } \\
\text { 혹은 참여할 자유를 평소만큼 } \\
\text { 느끼지 않는다. }\end{array}$ & $\begin{array}{l}\text { I do not feel as free as usual to travel, } \\
\text { or to participate in social } \\
\text { gatherings. }\end{array}$ & $\begin{array}{l}\text { 나는 여행을 하거나 사교 행사에 } \\
\text { 참석, 혹은 참여할 자유를 평소만큼 } \\
\text { 느끼지 않는다. }\end{array}$ \\
\hline $\begin{array}{l}\text { I have less ability than usual to } \\
\text { focus on my work, family, or other } \\
\text { commitments or interests }\end{array}$ & $\begin{array}{l}\text { 나는 일, 가족, 약속된 일들 혹은 관심 } \\
\text { 사에 집중할 능력이 평소보다 } \\
\text { 덜하다. }\end{array}$ & $\begin{array}{l}\text { I am less able than usual to } \\
\text { concentrate on my work, family, } \\
\text { appointments or interests. }\end{array}$ & $\begin{array}{l}\text { 나는 일, 가족, 임무 혹은 관심사에 } \\
\text { 집중할 능력이 평소보다 덜하다. }\end{array}$ \\
\hline $\begin{array}{l}\text { I need to make special } \\
\text { arrangements when traveling }\end{array}$ & 나는 여행 시 특별한 준비가 필요하다. & $\begin{array}{l}\text { I need special preparation } \\
\text { when traveling. }\end{array}$ & 나는 여행 시 특별한 조율이 필요하다. \\
\hline
\end{tabular}


of the questionnaire was easy to follow. They gave feedback on some expressions that were difficult to understand. One patient had difficulty in understanding "giryeok sujun" in question 1-A, which was translated from "energy level." After short panel discussion, the ward "sujun" was decided to be eliminated. Another one pointed out the meaning of "sagyo haengsa" which was translated from "social events." However, since this expression does not exist in Korean anyhow, panels decided to keep the original translated text. Another patient asked about the meaning of "gingeupchiryosil" (urgent care in the last session). It is a hospital facility that does not exist in the Korean medical system. No further grammatical errors or misunderstandings were found. The authors were able to confirm the completed Korean version of WISQOL (Fig. 2).

\section{DISCUSSION}

It is very important to assess the QoL of patients with urinary

\section{위스콘신 결석 삶의 질}

위스콘신 “신장 결석 환자로서의 삶” 설문지

이 설문지는 신장 결석 병력이 있는 환자들의 삶의 질을 이해하기 위해 고안되었습니다. 아래 질문들은 지난 한 달 동안 신장 결석 문제들이 귀하에게 어떤 영향을 끼첬는 지에 대해 묻슴니

몇몇 질문들은 매우 비슷해 보이거나 비숫한 문구를 가지고 있지만, 각각의 질문은 다릅니다. 질둔를에 대해 최대한 솔직하게 담변해 주심시오. 본 설문지는 양면임니다. 귀하가 여러 신체 주십시오. 모든 정보는 비밀이 보장됩니다. 기입해 주셔서 감사합니다.

1. 지난 4 주 동안 다음 서술들이 귀하에게 얼마나 해당됩니까?

1. 지난 4 주 동안 다음 서술들이 귀하에게 얼마나 해당됨니까?
\begin{tabular}{|l|c|c|c|c|c|}
\hline & $\begin{array}{c}\text { 매우 } \\
\text { 해당됨 }\end{array}$ & $\begin{array}{c}\text { 거의 } \\
\text { 해당됨 }\end{array}$ & $\begin{array}{c}\text { 다소 } \\
\text { 해당됨 }\end{array}$ & $\begin{array}{c}\text { 조금 } \\
\text { 해당됨 }\end{array}$ & $\begin{array}{c}\text { 전혀 해당 } \\
\text { 되지 않음 }\end{array}$ \\
\hline $\begin{array}{l}\text { A.) 낮 시간 동안 나의 기력이 평소보 } \\
\text { 다 덜하다. }\end{array}$ & 1 & 2 & 3 & 4 & 5 \\
\hline $\begin{array}{l}\text { B.) 나는 매우 지쳐 있거나 피곤하다 } \\
\text { 고 느낀다. }\end{array}$ & 1 & 2 & 3 & 4 & 5 \\
\hline C.) 나의 활동이 제한적이다. & 1 & 2 & 3 & 4 & 5 \\
\hline
\end{tabular}

2. 신장 결석으로 인해, 지난 4 주 동안 이 문제들이 (어떤 것이라도) 귀하에게 얼마나 해당되었습니까?

2. 신장 결석으로 인해, 지난 4 주 동안 이 문제들이 (어떤 것이라도) 귀하에게 얼마나 해당되었슨니까?
\begin{tabular}{|l|c|c|c|c|c|}
\hline & $\begin{array}{c}\text { 매우 } \\
\text { 해당됨 }\end{array}$ & $\begin{array}{c}\text { 거의 } \\
\text { 해당됨 }\end{array}$ & $\begin{array}{c}\text { 다소 } \\
\text { 해당됨 }\end{array}$ & $\begin{array}{c}\text { 조금 } \\
\text { 해당됨 }\end{array}$ & $\begin{array}{c}\text { 전혀 해당 } \\
\text { 되지 않음 }\end{array}$ \\
\hline $\begin{array}{c}\text { A.) 잠들기에 문제가 있거나, 자려고 } \\
\text { 노력하는 데도 깨는 문제가 있다. }\end{array}$ & 1 & 2 & 3 & 4 & 5 \\
\hline $\begin{array}{c}\text { B.) 소변을 보기 위해 잠자는 도중에 } \\
\text { 자주 깨야 할 필요가 있다. }\end{array}$ & 1 & 2 & 3 & 4 & 5 \\
\hline $\begin{array}{c}\text { C.) 수면의 질이 낮거나 자고 난 뒤 } \\
\text { 쉬었다는 느낌이 들지 않는다. }\end{array}$ & 1 & 2 & 3 & 4 & 5 \\
\hline D.) 다시 잠들기 힘들다. & 1 & 2 & 3 & 4 & 5 \\
\hline
\end{tabular}

3. 신장 결석으로 인해, 지난 4 주 동안 다음은 귀하에게 얼마나 해당됩니까?

\begin{tabular}{|c|c|c|c|c|c|}
\hline & $\begin{array}{c}\text { 매우 } \\
\text { 해당됨 }\end{array}$ & $\begin{array}{l}\text { 거의 } \\
\text { 해당됨 }\end{array}$ & $\begin{array}{l}\text { 다소 } \\
\text { 해당됨 }\end{array}$ & $\begin{array}{l}\text { 조금 } \\
\text { 해당됨 }\end{array}$ & $\begin{array}{l}\text { 전혀 해당 } \\
\text { 되지 않음 }\end{array}$ \\
\hline $\begin{array}{l}\text { A.) 나는 여행을 하거나 사교 행사에 } \\
\text { 참석, 혹은 참여할 자유를 } \\
\text { 평소만큼 느끼지 않는다. }\end{array}$ & 1 & 2 & 3 & 4 & 5 \\
\hline $\begin{array}{l}\text { B.) 나는 억지로 직장이나 학교에 } \\
\text { 가거나, 운동하거나 혹은 다른 } \\
\text { 책임들을 수행한다. }\end{array}$ & 1 & 2 & 3 & 4 & 5 \\
\hline $\begin{array}{l}\text { C.) 나는 일이나 가족과의 시간을 } \\
\text { 놓첬거나 여가나 오락 시간을 } \\
\text { 잃은 적이 있다. }\end{array}$ & 1 & 2 & 3 & 4 & 5 \\
\hline $\begin{array}{l}\text { D.) 나는 내 일과를 빈번히 } \\
\text { 조정하거나 변경한다. }\end{array}$ & 1 & 2 & 3 & 4 & 5 \\
\hline $\begin{array}{l}\text { E.) 나는 일, 가족, 임무 혹은 } \\
\text { 관심사에 집중할 능력이 } \\
\text { 평소보다 덜하다. }\end{array}$ & 1 & 2 & 3 & 4 & 5 \\
\hline
\end{tabular}

돗면에 있는 질문들에 대답해 주십시오. stone because many of them may experience recurrence after they have been properly treated. They may suffer from it like chronic diseases. The QoL of patients with urinary calculi tended to be neglected in the past. However, a questionnaire was developed to measure the inconvenience caused by ureteral stents earlier than urinary stone QoL [20]. About 10 years ago, papers about the QoL of patients with urinary stone began to be published $[11,14,15]$. Since then, the QoL for patients with urinary stone has been reported to be far worse and different than expected. In a prospective study assessing changes in QoL of patients who underwent PCNL for symptomatic caliceal diverticulum and deep lower-pole calculi, Staios et al. [15] concluded that, although stone-free rate was very high (87\%), fewer than half of these patients experienced subjective benefit. Bryant et al. [9] have demonstrated that stone formers suffer from not only physical functioning and bodily pain, but also lower social functioning and general health compared to the general population. Moreover, Bensalah et al. [8] have reported that the

\begin{tabular}{|c|c|c|c|c|c|}
\hline & $\begin{array}{l}\text { 항상 또는 } \\
\text { 거의 항상 }\end{array}$ & 매우 자주 & 다소 자주 & 거의 아님 & 전혀 아님 \\
\hline $\begin{array}{l}\text { A.) 식단 권장사항을 지키는 것에 } \\
\text { 대한 문제 혹은 어려움. }\end{array}$ & 1 & 2 & 3 & 4 & 5 \\
\hline $\begin{array}{l}\text { B.) 지시 받은 대로 처방약을 복용하 } \\
\text { 거나 견디는 것에 대한 문제 }\end{array}$ & 1 & 2 & 3 & 4 & 5 \\
\hline C.) 나의 전반적인 건강에 대한 걱정 & 1 & 2 & 3 & 4 & 5 \\
\hline \multicolumn{6}{|c|}{$\begin{array}{l}\text { 5. 이하는 신장 결석과 관련될 수 있는 몆몆 신체 증상들입니다. 지난 } 4 \text { 주 동안 귀하는 이 증상들을 } \\
\text { 얼마나 자주 느꼈슴니까? }\end{array}$} \\
\hline & $\begin{array}{l}\text { 항상 또는 } \\
\text { 거의 항상 }\end{array}$ & 매우 자주 & 다소 자주 & 거의 아님 & 전혀 아님 \\
\hline A.) 메스꺼움, 배탈, 혹은 위경련 & 1 & 2 & 3 & 4 & 5 \\
\hline B.) 신체 통증 & 1 & 2 & 3 & 4 & 5 \\
\hline $\begin{array}{l}\text { C.) 빈뇨 (평소보다 더 자주 소변을 } \\
\text { 봐야 한다고 느낌) }\end{array}$ & 1 & 2 & 3 & 4 & 5 \\
\hline $\begin{array}{l}\text { D.) 요절박 (갑작스럽거나 엄출 수 } \\
\text { 없이 소변을 보려는 충동) }\end{array}$ & 1 & 2 & 3 & 4 & 5 \\
\hline
\end{tabular}

6. 신장 결석으로 인해 지난 4 주 동안 다음이 커하에게 얼마나 해당됩니까?

6. 신장 결석으로 인해 지난 4 주 동안 다음이 거하에게 얼마나 해당됩니까?
\begin{tabular}{|l|c|c|c|c|c|}
\hline & $\begin{array}{c}\text { 매우 } \\
\text { 해당됨 }\end{array}$ & $\begin{array}{c}\text { 거의 } \\
\text { 해당됨 }\end{array}$ & $\begin{array}{c}\text { 다소 } \\
\text { 해당됨 }\end{array}$ & $\begin{array}{c}\text { 조금 } \\
\text { 해당됨 }\end{array}$ & $\begin{array}{c}\text { 전혀 해당 } \\
\text { 되지 않음 }\end{array}$ \\
\hline $\begin{array}{c}\text { A.) 나는 성관계에 대한 관심이 덜하 } \\
\text { 거나 성적인 접촉이 평소보다 덜 } \\
\text { 하다. }\end{array}$ & 1 & 2 & 3 & 4 & 5 \\
\hline $\begin{array}{l}\text { B.) 나는 여행시 득별한 조율이 필요 } \\
\text { 하다. }\end{array}$ & 1 & 2 & 3 & 4 & 5 \\
\hline $\begin{array}{l}\text { C.) 나는 평소보다 사교/타인과 어울 } \\
\text { 리는 것에 관심이 덜하다. }\end{array}$ & 1 & 2 & 3 & 4 & 5 \\
\hline
\end{tabular}

7. 지난 4 주 동안, 신장 결석으로 인해 다음을 얼마나 느꼈슴니까?

\begin{tabular}{|c|c|c|c|c|c|c|}
\hline & 매우 & 뫠 많이 & 다소 & & 조금 & 전혀 \\
\hline A.) 나의 상황에 대한 좌젇감 & 1 & 2 & 3 & & 4 & 5 \\
\hline $\begin{array}{l}\text { B.) 현재 무엇이 잘못되었나에 대한 } \\
\text { 걱정 }\end{array}$ & 1 & 2 & 3 & & 4 & 5 \\
\hline $\begin{array}{l}\text { C.) 미래에 무언가 잘못될 수도 있을 } \\
\text { 것에 대한 불안감 혹은 초조함 }\end{array}$ & 1 & 2 & 3 & & 4 & 5 \\
\hline $\begin{array}{l}\text { D.) 내 상황의 번거로움과 불편함에 } \\
\text { 대한 짜증 }\end{array}$ & 1 & 2 & 3 & & 4 & 5 \\
\hline $\begin{array}{l}\text { E.) 평소와 비교해 일상의 일들 혹은 } \\
\text { 책임을 다루는데 있어서의 능력 } \\
\text { 저하 }\end{array}$ & 1 & 2 & 3 & & 4 & 5 \\
\hline F.) 평소보다 짜증이 더 잘남 & 1 & 2 & 3 & & 4 & 5 \\
\hline \multicolumn{7}{|c|}{ 지난 4 주간의 귀하에 대한 몇 가지 질문 (당신의 응답에 동그라미를 쳐주심시오): } \\
\hline \multirow{2}{*}{\multicolumn{4}{|c|}{ 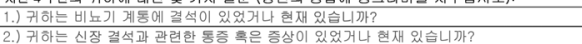 }} & all & OFLL오 & 화실리치 앙음 \\
\hline & & & & afl & 아니오 & 확실치 앙응음 \\
\hline \multirow{2}{*}{\multicolumn{4}{|c|}{ 3.) 귀하는 신장 걸석으로 인해 응를실 혹은 긴급치료실을 관 적이 있습니까? }} & af & 아니오 & 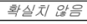 \\
\hline & & & & af & OFLL오 & 확실치 안음 \\
\hline \multicolumn{4}{|c|}{ 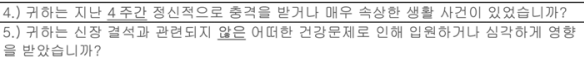 } & off & 아니오 & 확실치 압음 \\
\hline \multicolumn{4}{|c|}{ 6.) 귀하의 성별 (동그라미를 쳐주십시오): $\quad$ 남성 $\quad$ 여성 } & \multicolumn{3}{|c|}{ 7.) 귀하의 나이: } \\
\hline
\end{tabular}

6.) 귀하의 성별 (동그라미를 쳐주십시오): 남성 여성

Fig. 2. The Korean version of Wisconsin Stone Quality of Life Questionnaire. 
number of stone episodes does not influence QoL. However, the number of ureteroscopic surgery and stent placement have impacted their mental health [11].

One of the important disadvantages in these papers was that a 36-Item Short-Form General Health Survey (SF-36) questionnaire was used as a tool for QoL assessment. The SF-36 was initially designed as a general scale to predict QoL of an individual [10]. Donnally et al. [10] reported that 18 of 96 patients (18.8\%) reported a stone event within the month preceding completion of the initial questionnaire. However, these 18 patients had no stone event prior to follow-up survey or changes in any SF-36 domain between the first and follow-up questionnaires. Thus, they concluded that the absence of significant changes in SF-36 scores despite changes in stone status suggested that SF-36 might not be an adequate tool to monitor QoL in stone patients [10]. In recognition of the need for a questionnaire specific to patients with urinary stone, Penniston and Nakada [7] have developed WISQOL as an instrument to access the health-related QoL of kidney stone formers. They made 65 items at first related to stone formers and eliminated 37 questions that had less impact factor through an item reduction process [10]. The WISQOL was externally validated with 1,609 stone patients from 9 academic stone centers in the United States and Englishspeaking Canada [21]. It was found that WISQOL was superior to SF-36v2 in identifying health-related QoL related decrements, confirming its convergent validity. Further studies have cited and used WISQOL as a useful tool to evaluate health-related QoL of stone formers $[6,12,13]$.

It is not easy to translate questionnaires developed in foreign languages into other languages [22]. Since a small mistake can cause a big difference in meaning, translation work must be done through several confirmation procedures. The authors were able to complete the Korean version of WISQOL through precise procedures proven previously $[18,19,23]$. In addition, good feedbacks were received from patients who had answered the questionnaire.

Our study has several limitations, including the small number of patients who participated in cognitive briefing. However, the authors sought to improve the accuracy of the screening by selecting patients of various ages with different educational levels. Another limitation of this study was that there was no external validation at all. This needs to be addressed in a further study. However, to our knowledge, this is the first questionnaire available in Korea to assess the QoL of urinary stone formers. Our results are significant because the Korean version of
WISQOL would be a generally reliable instrument for urinary stone patients.

In conclusion, the present study describes details for the development of Korean version of WISQOL. Our results might be widely used in real practice between urologists who treat and care urinary lithiasis patients. A further large-scale validation study is needed. The use of this questionnaire is expected to have a positive impact on patient care.

\section{SUPPLEMENTARY MATERIALS}

Supplementary Tables 1-2 can be found via https://doi.org/ 10.5213/inj.1836238.119.

\section{AUTHOR CONTRIBUTION}

- Conceptualization: SYC

- Data curation: SYC

- Formal Analysis: YEY, SYC

- Investigation: YEY, SYC

- Methodology: YEY, SYC

- Validation : YEY, SYC

- Project Administration: SYC

-Writing - Original Draft: YEY

-Writing - Review \& Editing: SYC

\section{REFERENCES}

1. Siener R, Hesse A. Fluid intake and epidemiology of urolithiasis. Eur J Clin Nutr 2003;57 Suppl 2:S47-51.

2. Mitra P, Pal DK, Das M. Does quality of drinking water matter in kidney stone disease: a study in West Bengal, India. Investig Clin Urol 2018;59:158-65.

3. Park J, Suh B, Lee MS, Woo SH, Shin DW. National practice pattern and time trends in treatment of upper urinary tract calculi in Korea: a nationwide population-based study. J Korean Med Sci 2016;31:1989-95.

4. Heers H, Turney BW. Trends in urological stone disease: a 5-year update of hospital episode statistics. BJU Int 2016;118:785-9.

5. Modersitzki F, Pizzi L, Grasso M, Goldfarb DS. Health-related quality of life (HRQoL) in cystine compared with non-cystine stone formers. Urolithiasis 2014;42:53-60.

6. Penniston KL, Sninsky BC, Nakada SY. Preliminary evidence of decreased disease-specific health-related quality of life in asymptomatic stone patients. J Endourol 2016;30 Suppl 1:\$42-5. 
7. Penniston KL, Nakada SY. Development of an instrument to assess the health related quality of life of kidney stone formers. J Urol 2013;189:921-30.

8. Bensalah K, Tuncel A, Gupta A, Raman JD, Pearle MS, Lotan Y. Determinants of quality of life for patients with kidney stones. J Urol 2008;179:2238-43; discussion 2243.

9. Bryant M, Angell J, Tu H, Goodman M, Pattaras J, Ogan K. Health related quality of life for stone formers. J Urol 2012;188:436-40.

10. Donnally CJ 3rd, Gupta A, Bensalah K, Tuncel A, Raman J, Pearle MS, et al. Longitudinal evaluation of the SF-36 quality of life questionnaire in patients with kidney stones. Urol Res 2011;39:141-6.

11. Penniston KL, Nakada SY. Health related quality of life differs between male and female stone formers. J Urol 2007;178:2435-40; discussion 2440 .

12. Zhao PT, Hoenig DM, Smith AD, Okeke Z. A randomized controlled comparison of nephrostomy drainage vs ureteral stent following percutaneous nephrolithotomy using the Wisconsin StoneQOL. J Endourol 2016;30:1275-84.

13. Jiang H, Huang D, Yao S, Liu S. Improving drainage after percutaneous nephrolithotomy based on health-related quality of life: a prospective randomized study. J Endourol 2017;31:1131-8.

14. Diniz DH, Blay SL, Schor N. Quality of life of patients with nephrolithiasis and recurrent painful renal colic. Nephron Clin Pract 2007;106:c91-7.

15. Staios D, Andrews HO, Shaik T, Buchholz NN. Quality of life after percutaneous nephrolithotomy for caliceal diverticulum and secluded lower-pole renal stones. J Endourol 2007;21:515-9.

16. Angell J, Bryant M, Tu H, Goodman M, Pattaras J, Ogan K. Association of depression and urolithiasis. Urology 2012;79:518-25.
17. Pérez-Fentes DA, Gude F, Blanco B, Freire CG. Percutaneous nephrolithotomy: short- and long-term effects on health-related quality of life. J Endourol 2015;29:13-7.

18. Lee HN, Chae JY, Lee HS, Choo MS, Park MG, Lee SY, et al. Translation and linguistic validation of the Korean version of the treatment satisfaction visual analogue scale and the overactive bladder satisfaction with treatment questionnaire. Int Neurourol J 2017;21: 309-19.

19. Cho SY, Lee HE, Jeong SJ, Oh SJ. Translation and linguistic validation of the Korean version of the "benefit, satisfaction, and willingness to continue" questionnaire for patients with overactive bladder. Int Neurourol J 2016;20:255-9.

20. Joshi HB, Newns N, Stainthorpe A, MacDonagh RP, Keeley FX Jr, Timoney AG. Ureteral stent symptom questionnaire: development and validation of a multidimensional quality of life measure. J Urol 2003;169:1060-4.

21. Penniston KL, Antonelli JA, Viprakasit DP, Averch TD, Sivalingam S, Sur RL, et al. Validation and reliability of the Wisconsin Stone Quality of Life Questionnaire. J Urol 2017;197:1280-8.

22. Chuang FC, Hsiao SM, Kuo HC. The Overactive Bladder Symptom Score, International Prostate Symptom Score-Storage Subscore, and Urgency Severity Score in patients with overactive bladder and hypersensitive bladder: which scoring system is best? Int Neurourol J 2018;22:99-106.

23. Kim M, Lee HE, Kim SH, Cho SY, Jeong SJ, Oh SJ, et al. Korean version of the functional assessment of cancer therapy (FACT)vanderbilt cystectomy index (VCI): translation and linguistic. Urol J 2014;11:1961-7. 